Plasma hyperosmolality stimulates the neurosecretory neurons in the supraoptic and paraventricular nuclei of the hypothalamus to release antidiuretic hormone via the posterior pituitary which stimulates reabsorption of pure water from the distal tubules of the kidney. At first glance, it would seem reasonable that the patient receiving osmotic agents would have a decreased urinary production. Clinical experience indicates that this is not the case and that patients so treated experience a sizeable hypotonic diuresis. This apparent paradox is readily understood if one recognizes the dual control exercised over diuresis. Increased intrathoracic, intravascular volume is a strong stimulus inducing rapid hypotonic diuresis. This control system overrides that mediated by way of the osmo-receptors of the hypothalamus so that the patient receiving a large volume of mannitol experiences diuresis in spite of the primary increased serum hyperosmolality. The induced hypotonic diuresis increases the concentration of all molecular and ions within the plasma (the most significant of which is sodium) and creates a secondary hyperosmolar state in the plasma which adds to and prolongs the primary direct effect of the intravenously administered osmotic agent. This secondary hypotonic diuresis is exaggerated as the volume administered is increased or in direct proportion to the molecular size of the osmotic agent. The latter is a factor since agents such as mannitol (mol. wt. i8o) remain in the blood vessels and induce the movement of extravascular fluid into the vascular compartments, thereby increasing the blood volume substantially above that caused by the actual infusion of mannitol. Agents such as urea, which easily escape from the blood vessels, do not cause as much increase in the blood volume and thus induce less hypotonic diuresis and secondary osmotic effect.

Mannitol achieves its osmotic effect by both a primary initial effect and a secondary hyperosmolar state; urea also has a dual effect but can be expected to be less effective than mannitol in both the primary and secondary modes of action.

Ethyl alcohol is relatively ineffective as a primary osmotic agent and exerts most of its effect through secondary hyperosmolality induced by hypotonic diuresis. It has a specific depressant effect on the neurosecretory neurons of the supraoptic and paraventricular nucleus and reduces the output of antidiuretic hormone from the posterior pituitary, thereby inducing a serum hyperosmolality relating to hypotonic diuresis.

\title{
Medical versus surgical therapy in glaucoma simplex
}

\author{
REDMOND J.H. SMITH \\ London
}

Miller (1955) stated that as far as he knew the literature contained no description of a prospective trial of medical versus surgical therapy in glaucoma simplex.

A trial has therefore been proceeding at Moorfields since r 964 . The preliminary results were described by Smith (1968). 


\section{Brief recapitulation of material and methods}

Cases of glaucoma simplex with visual field loss and intraocular pressures of $23 \mathrm{~mm} . \mathrm{Hg}$ or more on at least two separate occasions were studied. Only one eye was studied in each patient. The other eye was observed and managed as appropriate but does not figure in any of the published results. Patients with other substantial eye abnormalities and patients of Negroid stock were excluded from the trial.

Once a patient had been admitted to the trial the usual examination was carried out and the following principal items of data recorded: intraocular pressure at the 'admittance' examination, visual acuity and visual field with a $0.5^{\circ}$ white target on a Lister automatic recording perimeter using the standard illumination in a room with normal artificial lighting. The visual field was scored as a percentage by Fisher's method and the visual acuity was also expressed as a percentage.

The patient was then selected for surgical or medical treatment by reference to a table of random numbers. Considerable ethical problems could have arisen at this point, but in practice this aspect of the trial seems to have given no trouble.

The surgical operation (Scheie's procedure with sector iridectomy) was performed in due course, not always immediately, and the patients were re-examined 3-monthly. Thus it was hoped that, as time went on, the effect of the surgical procedure on the fate of the two groups might become apparent in the ocular tensions, visual acuities, and visual fields. All the patients in each group were given as full medical treatment as was deemed necessary in each case on the normal clinical criteria.

\section{Results}

The initial data of the patients is presented in Table I. There are no significant differences between the groups and the apparent preponderance of males (37: 15) fails to achieve significance by the $\chi^{2}$ test.

Table I Initial comparability

\begin{tabular}{|c|c|c|c|}
\hline \multicolumn{2}{|c|}{ Particulars } & Medical & Surgical \\
\hline \multicolumn{2}{|c|}{ No. of patients } & 27 & 25 \\
\hline \multicolumn{2}{|c|}{ Mean age (yrs) } & $59^{\circ} 9$ & $57 \cdot 7$ \\
\hline \multirow[t]{2}{*}{ Sex } & Male & I 7 & 20 \\
\hline & Female & Io & 5 \\
\hline \multirow[t]{2}{*}{ Eye } & Right & I 6 & 12 \\
\hline & Left & I I & 14 \\
\hline \multirow{2}{*}{\multicolumn{2}{|c|}{$\begin{array}{l}\text { Mean intraocular pressure } \\
\text { Mean visual acuity } \\
\text { Mean visual field }\end{array}$}} & & 25 \\
\hline & & $\begin{array}{l}76 \\
66 \cdot 8\end{array}$ & $\begin{array}{l}72 \\
69 \cdot 0\end{array}$ \\
\hline
\end{tabular}

An attempt to study the progress of the patients has been made by studying the means of the various parameters at regular intervals to see if significant differences between the medical and surgical groups emerged.

For the sake of brevity in the present analysis, only the figures for each annual period are shown. Thus we may study the situation at I year, 2 years, and so on after admittance to the trial. The figures for each period refer to the numbers of patients in each group with the appropriate length of follow-up. Thus, for each period, fewer patients appear as not all patients entered the trial at the same time. At I year there will be many more patients available for study than at say 4 years. 
Intraocular pressure (Table II)

A clear benefit from surgery is present at I, 2, and 3 years, but later becomes non-significant. There are two reasons for this: the numbers in the longer follow-up groups are rather small and by this time a good proportion of the 'medical' patients had been operated on because of a deterioration in their visual fields. Actually, in the $4^{\text {th }}, 5^{\text {th }}$, and 6 th years (i.e. by 1970) 40, 50, and 75 per cent. of the patients respectively had been operated on.

Table II Intraocular pressure (1970 figures)

\begin{tabular}{|c|c|c|c|c|c|c|}
\hline Time (yrs) & I & 2 & 3 & 4 & 5 & 6 \\
\hline $\begin{array}{l}\text { No. of medical cases } \\
\text { Mean intraocular pressure }(\mathrm{mm} . \mathrm{Hg})\end{array}$ & $2 \mathrm{I}$ & 21 & I 5 & I 2 & 8 & 5 \\
\hline $\begin{array}{l}\text { No. of surgical cases } \\
\text { Mean intraocular pressure }(\mathrm{mm} . \mathrm{Hg})\end{array}$ & $\begin{array}{l}21 \\
15\end{array}$ & $\begin{array}{l}19 \\
15\end{array}$ & $\begin{array}{l}15 \\
16\end{array}$ & $\begin{array}{l}\text { I I } \\
18\end{array}$ & $\begin{array}{r}5 \\
17\end{array}$ & $\begin{array}{r}3 \\
13\end{array}$ \\
\hline $\begin{array}{l}\text { Difference between medical } \\
\text { and surgical cases }\end{array}$ & 8 & 7 & 6 & 3 & 3 & 2 \\
\hline Significance & $\mathrm{P}<0.00 \mathrm{I}$ & $\mathrm{P}<0.0 \mathrm{I}$ & $\mathrm{P}<0 . \mathrm{OI}$ & NS & NS & NS \\
\hline
\end{tabular}

\section{Visual acuity (Table III)}

The results here are very disturbing and show that a serious decline in visual acuity occurs in both groups. None of the acuity differences are significant, however, and the position is again much complicated by the fact that operations were carried out on some of the medical patients later in the series. However, by 1970, there appears to be a possible slight advantage to the surgical group.

Table III Visual acuity (1970 figures)

\begin{tabular}{|c|c|c|c|c|c|c|}
\hline Time (yrs) & I & 2 & 3 & 4 & 5 & 6 \\
\hline $\begin{array}{l}\text { No. of medical cases } \\
\text { Mean acuity (per cent.) }\end{array}$ & $\begin{array}{l}22 \\
72\end{array}$ & $\begin{array}{l}21 \\
52\end{array}$ & $\begin{array}{l}15 \\
51\end{array}$ & $\begin{array}{l}\text { I I } \\
53\end{array}$ & $\begin{array}{r}7 \\
47\end{array}$ & $\begin{array}{r}5 \\
34\end{array}$ \\
\hline $\begin{array}{l}\text { No. of surgical cases } \\
\text { Mean acuity(per cent.) }\end{array}$ & $\begin{array}{l}2 \mathrm{I} \\
6 \mathrm{I} \\
\end{array}$ & $\begin{array}{l}18 \\
47\end{array}$ & $\begin{array}{l}\text { I } 5 \\
54\end{array}$ & $\begin{array}{l}\text { I I } \\
47\end{array}$ & $\begin{array}{r}4 \\
5^{6}\end{array}$ & $\begin{array}{r}3 \\
55\end{array}$ \\
\hline $\begin{array}{l}\text { Difference between } \\
\text { medical and surgical } \\
\text { cases }\end{array}$ & I I & 5 & -3 & 6 & -9 & $-2 I$ \\
\hline Significance & NS & NS & NS & NS & NS & NS \\
\hline
\end{tabular}

Visual field (Table IV, overleaf)

All the differences are in favour of the surgical group but none achieve significance. Once more the picture is complicated by the fact that many of the 'medical' cases which showed serious deterioration were operated on by 197 I.

To remove these later surgical cases from the figures would introduce selection in favour of the medical group, because clearly one would be removing unfavourable cases whereas the whole surgical population was allowed to remain. All that is shown, therefore, by these figures is the effect of the decision to operate early. One is learning very little about the operation itself. 
Table IV Visual fields (1971 figures)

\begin{tabular}{|c|c|c|c|c|c|c|}
\hline Time (yrs) & I & 2 & 3 & 4 & 5 & 6 \\
\hline $\begin{array}{l}\text { No. of medical cases } \\
\text { Mean field per cent. }\end{array}$ & $\begin{array}{l}23 \\
63\end{array}$ & $\begin{array}{l}20 \\
59\end{array}$ & $\begin{array}{l}18 \\
55\end{array}$ & $\begin{array}{l}14 \\
49\end{array}$ & $\begin{array}{r}7 \\
40\end{array}$ & $\begin{array}{r}8 \\
42\end{array}$ \\
\hline $\begin{array}{l}\text { No. of surgical cases } \\
\text { Mean field per cent. }\end{array}$ & $\begin{array}{l}21 \\
69\end{array}$ & $\begin{array}{l}22 \\
68\end{array}$ & $\begin{array}{l}17 \\
59\end{array}$ & $\begin{array}{l}12 \\
56\end{array}$ & $\begin{array}{r}8 \\
57\end{array}$ & $\begin{array}{r}3 \\
53\end{array}$ \\
\hline $\begin{array}{l}\text { Difference between } \\
\text { medical and surgical } \\
\text { cases }\end{array}$ & -6 & -9 & -4 & -7 & -17 & $-\mathbf{I I}$ \\
\hline Significance & NS & NS & NS & NS & NS & NS \\
\hline
\end{tabular}

Another problem, if we assume for a moment that surgery does bring some benefit, concerns the mechanism by which this is achieved. It might be unrelated to improvement in intraocular pressure but due to alteration in pupil sizes.

Another way of looking at the problem is to study only the patients who actually had surgery whether they came from the medical or the surgical group. Their individual scores are shown in Tables V and VI, and there are eighteen suitable patients which can $\widehat{S}$ be studied in this way. Not all the surgical patients are included, as some had their oper- $\frac{\vec{c}}{6}$ ation early and there is therefore no reasonable preoperative period in which to study their $N$ regression.

Table $\mathbf{V}$ Visual field scores before surgery

\begin{tabular}{|c|c|c|}
\hline Group & Patient no. & Visual field scores \\
\hline \multirow[t]{10}{*}{ Medical } & $\mathbf{I}$ & $\begin{array}{lllllllllllllllllllllll}86 & 80 & 84 & 90 & 80 & 90 & 85 & 82 & 72 & 81 & 71 & 62 & 80 & 70 & 80 & 70 & 75 & 70 & 52 & 53 & 46 & 49 & 56\end{array}$ \\
\hline & 2 & 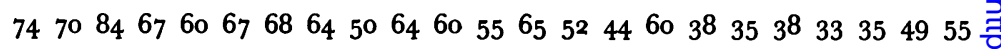 \\
\hline & 3 & $\begin{array}{llllllllllll}77 & 80 & 87 & 80 & 83 & 65 & 78 & 78 & 76 & 74 & 70 & 63\end{array}$ \\
\hline & 4 & $20192925191210 ?$ \\
\hline & 5 & 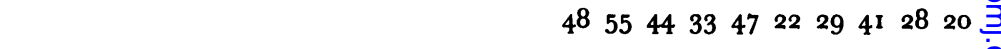 \\
\hline & 6 & $979796898890818483 @$ \\
\hline & 7 & 805871606655 \\
\hline & 8 & 60544530 \\
\hline & 9 & \begin{tabular}{lllllllllllllll}
26 & 32 & 39 & 34 & 22 & 22 & 34 & 48 & 58 & 30 & 27 & 21 & 9 & io & \multicolumn{1}{c}{}
\end{tabular} \\
\hline & 10 & $\begin{array}{lll}554531 & 0 \\
\end{array}$ \\
\hline \multirow[t]{8}{*}{ Surgical } & II & 64656960 \\
\hline & 12 & 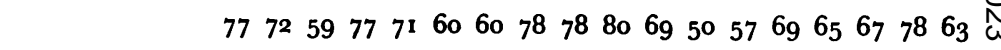 \\
\hline & 13 & 92878681 \\
\hline & 14 & 646560635038 \\
\hline & 15 & $\begin{array}{lllllllll}70 & 75 & 62 & 63 & 65 & 58 & 69 & 70\end{array}$ \\
\hline & 16 & 606055 \\
\hline & 17 & 353732 \\
\hline & 18 & 787288 \\
\hline Months & & 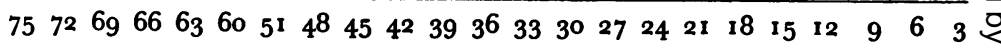 \\
\hline
\end{tabular}


Table VI Visual field scores after surgery

\begin{tabular}{|c|c|c|}
\hline Group & Patient no. & Visual field scores \\
\hline \multirow[t]{10}{*}{ Medical } & I & $\begin{array}{lllllll}59 & 50 & 62 & 5^{8} & 5^{0} & 5^{8}\end{array}$ \\
\hline & 2 & $\begin{array}{lllllll}56 & 59 & 63 & 79 & 57 & 57 & 73\end{array}$ \\
\hline & 3 & 707363516 I 53 \\
\hline & 4 & $\begin{array}{llllllllllllllllll}9 & 11 & 3 & 12 & 6 & 6 & 16 & 12 & 6 & 13 & 4 & 5 & 5 & 5 & 5 & 5 & 5 & 5\end{array}$ \\
\hline & 5 & 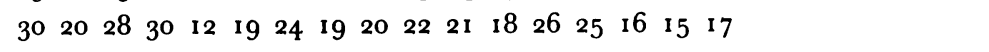 \\
\hline & 6 & $\begin{array}{lllllllllllllllll}85 & 88 & 74 & 83 & 88 & 81 & 81 & 80 & 75 & \end{array}$ \\
\hline & 7 & $\begin{array}{lllllllllllll}6_{5} & 62 & 69 & 6_{5} & 67 & 72 & 6_{4} & 6_{4} & 63 & 62 & 81 & 70 & 78\end{array}$ \\
\hline & 8 & 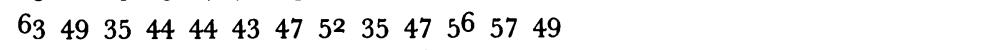 \\
\hline & 9 & $\begin{array}{lllllllllllll}7 & 9 & 9 & 28 & 20 & 22 & 5 & 7 & 29 & 26 & 30 & 30 & 30\end{array}$ \\
\hline & 10 & $455^{0} 4^{8} 5^{8} \quad 55 \quad 55 \quad 4553$ \\
\hline \multirow[t]{8}{*}{ Surgical } & II & 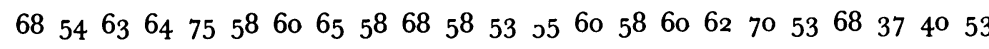 \\
\hline & 12 & 6262 \\
\hline & 13 & $\begin{array}{llllllllllllllllllll}81 & 80 & 73 & 75 & 85 & 84 & 85 & 86 & 80 & 84 & 89 & 84 & 85 & 80 & 77 & 80 & 80 & 73 & 76 & 83\end{array}$ \\
\hline & 14 & 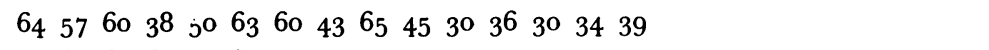 \\
\hline & 15 & 676164615980 \\
\hline & 16 & $\begin{array}{llllllll}5^{2} & 4^{1} & 57 & 60 & 68 & 5^{6} & 5^{8} & 59\end{array}$ \\
\hline & 17 & $3^{2} \quad 30 \quad 334^{1} \quad 34 \quad 47$ \\
\hline & 18 & 939595958895 \\
\hline Months & & $\begin{array}{lllllllllllllllllllllll}3 & 6 & 9 & 12 & 15 & 18 & 21 & 24 & 27 & 30 & 33 & 36 & 39 & 42 & 45 & 4^{8} & 51 & 54 & 57 & 60 & 63 & 66 & 6 g\end{array}$ \\
\hline
\end{tabular}

If we calculate the regression of the visual field on time for each patient before and after surgery, we may hope that the means of such regressions would look something like Fig. I.

The idea would be that the visual field declined before surgery, recovered after surgery because of a pupillary effect, and then declined again. The hope would be that the postsurgical decline would go on at a slower rate if there was a true benefit to intraocular pressure.

The results are shown in Table VII (overleaf); there is a distinct difference between the means of the preoperative and postoperative regressions (Fig. 2).

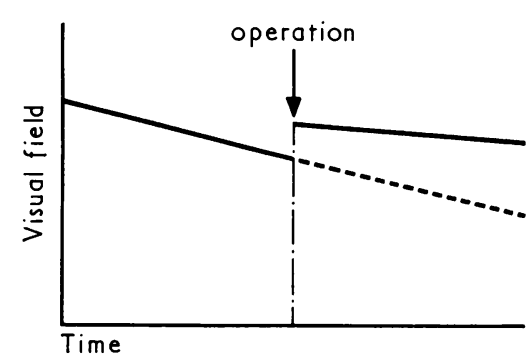

FIG. I Hypothetical regression of visual field before and after surgery

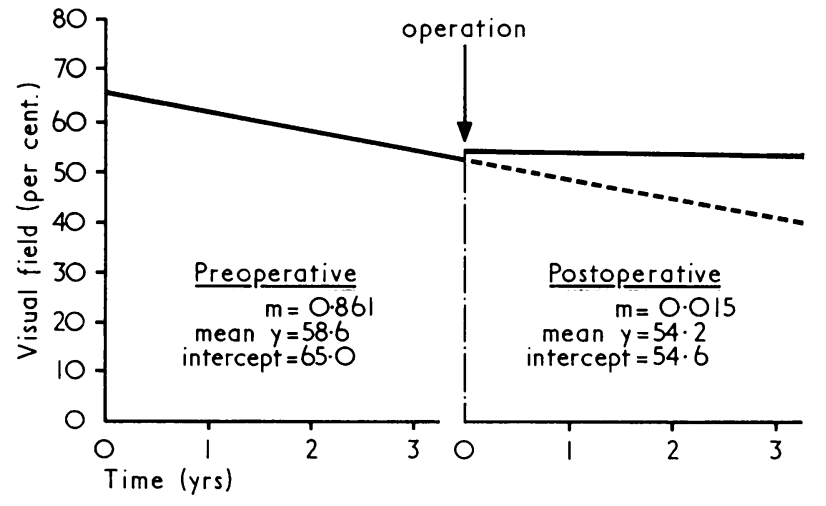

FIG. 2 Means of all regressions. Mean ys and mean $y$ intercepts 
If it could be proved that these results were statistically significant, we should now be in a position to say with some confidence that surgery offers a definite benefit to the visual fields. Table VII shows the results before and after surgery.

Table VII Individual regressions: before and after operation

\begin{tabular}{|c|c|c|c|c|c|c|}
\hline \multirow{2}{*}{$\begin{array}{l}\text { Patient } \\
\text { no. }\end{array}$} & \multicolumn{3}{|c|}{ Preoperative } & \multicolumn{3}{|c|}{ Postoperative } \\
\hline & $m$ & $\begin{array}{l}\text { mean } y \\
\text { average }\end{array}$ & $\begin{array}{l}\text { mean y } \\
\text { intercept }\end{array}$ & $m$ & $\begin{array}{l}\text { mean } y \\
\text { average }\end{array}$ & $\begin{array}{l}\text { mean } y \\
\text { intercept }\end{array}$ \\
\hline I & -0.55 & $72 \cdot 3$ & $90 \cdot 6$ & $-1 \cdot 03$ & $5^{2} \cdot 8$ & $6 o \cdot 6$ \\
\hline 2 & -0.49 & $5^{6 \cdot 8}$ & $73 \cdot 1$ & +0.49 & $63 \cdot 4$ & $59 \cdot 0$ \\
\hline 3 & $-0 \cdot 4^{2}$ & $75 \cdot 9$ & $82 \cdot 7$ & $-1 \cdot 27$ & $6 \mathrm{I} \cdot 8$ & $71 \cdot 3$ \\
\hline 4 & -0.64 & $19 \cdot 1$ & $24 \cdot 9$ & -0.09 & $07 \cdot 1$ & $09 \cdot 5$ \\
\hline 5 & -0.99 & $36 \cdot 7$ & $5^{0 \cdot 1}$ & -0.09 & $21 \cdot 8$ & $24 \cdot I$ \\
\hline 6 & $-0 \cdot 69$ & $89 \cdot 4$ & $97 \cdot 7$ & -0.40 & $80 \cdot 6$ & $86 \cdot 1$ \\
\hline 7 & $-\mathbf{I} \cdot 07$ & $65 \cdot 0$ & $73^{\circ} 0$ & +0.06 & $67 \cdot 8$ & $63 \cdot 2$ \\
\hline 8 & $-3 \cdot 30$ & $47 \cdot 3$ & $62 \cdot 1$ & $+0 \cdot 06$ & $48 \cdot 1$ & $47^{\circ} 0$ \\
\hline 9 & -0.37 & $29 \cdot 4$ & $36 \cdot 7$ & +0.55 & $19 \cdot 0$ & $09 \cdot 1$ \\
\hline Io & -4.00 & $43 \cdot 7$ & $55^{\cdot 6}$ & +0.19 & $5^{I \cdot I}$ & $49^{\circ} \mathrm{o}$ \\
\hline I I & -0.27 & $64 \cdot 5$ & $65 \cdot 7$ & $-0 \cdot 20$ & $59-I$ & $65 \cdot 8$ \\
\hline 12 & $-0 \cdot 10$ & $68 \cdot 3$ & $70 \cdot 9$ & $0 \cdot 00$ & $62 \cdot 0$ & $62 \cdot 0$ \\
\hline I 3 & $-1 \cdot 13$ & $86 \cdot 5$ & $9^{1} \cdot 6$ & $0 \cdot 00$ & $81 \cdot 3$ & $8 I \cdot 4$ \\
\hline 14 & $-\mathbf{r} \cdot 63$ & $56 \cdot 7$ & $69 \cdot 0$ & $-0 \cdot 64$ & $47 \cdot 9$ & $6 \mathrm{r} \cdot 3$ \\
\hline I 5 & $-0 \cdot 18$ & $67 \cdot 1$ & $69 \cdot 0$ & +0.53 & $65 \cdot 3$ & $6 \mathrm{I} \cdot 3$ \\
\hline I 6 & -0.83 & $5^{8 \cdot 3}$ & $6 o \cdot 8$ & +0.56 & $56 \cdot I$ & $50 \cdot 3$ \\
\hline 17 & -0.50 & $34 \cdot 7$ & $36 \cdot \mathbf{I}$ & +0.90 & $36 \cdot 1$ & $29 \cdot 3$ \\
\hline 18 & $+\mathrm{r} \cdot 67$ & $79 \cdot 3$ & $74 \cdot 3$ & -0.09 & $93 \cdot 2$ & $93 \cdot 8$ \\
\hline Mean & $-0.86 \mathrm{I}$ & $5^{8 \cdot 6}$ & $65 \cdot 0$ & -0.015 & $54 \cdot 2$ & $54^{\cdot 6}$ \\
\hline
\end{tabular}

In Table VIII, the regressions before and after surgery have been studied as paired data for each patient. This analysis shows that there is a significant difference with a probability between $\cdot 02$ and $\cdot 01$. This gratifying result could probably have been expected from a simple observation of the figures in Table VII because in there on the preoperative side

Table VIII $t$ test on the regressions before and after surgery studied as paired data

$$
\begin{aligned}
n & =18.00 \\
\Sigma(y-x) & =15.22 \\
\Sigma(y-x)^{2} & =44.33 \\
(y-x) & =0.845 \\
t & =2.635 \\
n-1 & =17.00 \\
\mathrm{P} & <.02>.01
\end{aligned}
$$


only one regression showed a postoperative sign, whereas on the postoperative side no less than eight showed a positive sign and two were zero. The mean of the preoperative regressions was $-0.86 \mathrm{I}$, whereas that of the postoperative regressions was only -0.0 5 .

I should, however, be cautious in accepting these facts at their face value, as the individual regressions tend to have rather high standard errors, but it is certainly suggestive that there is a true slowing up of field deterioration after surgery in these cases.

\section{Discussion}

My main impression from my attempts to solve this problem over the years is that the matter is amazingly complicated. If one knew that at a certain pressure a particular eye would go blind from glaucoma in a certain time, and if one could confidently predict an improvement in this prognosis by successful surgery one would be in a powerful position.

Unfortunately, the true position is very far from this. All the parameters are very poorly understood. We cannot relate prognosis at all reliably to pressure; we cannot predict whether our operation will succeed. In fact we know that sometimes the operation will be disastrous and, even if it does succeed pressure-wise, we do not know in any individual patient what improvement, if any, we have brought to the prognosis. There are so many variable factors.

What we cannot predict for an individual, however, we may yet be able to predict for a group, and I feel that it is probably worth while to carry on with the present investigation.

Regarding the analysis of results, an enormous amount of work still remains to be done, quite apart from the matter of keeping the trial going.

From the point of view of the future conduct and the improved analysis of the trial, there are many other aspects in which more work is needed.

Although I have calculated the field regression as a straight line, this is an artificial method if only because the scoring of the visual fields is not itself linear, but just an arbitrary scoring system: and in any case, even if it were linear for area, different areas of the visual field clearly carry quite different "usefulness values" as far as the patient is concerned.

The method of charting the fields is rather crude, and I wish now that I had adopted a more closely controlled system, but the object was to simulate the normal clinical methods in use at the time of starting the trial.

In any future work of this sort I should prefer to use a fixed static programme which would be the same for all patients. Such a programme could be provided on any good static perimeter, but the simplest for this sort of work would probably be a Friedman at zero setting.

Many correlations need to be sought, correlations of intraocular pressure, age, visual acuity, and visual field could all be looked at. Furthermore, there is no certainty that the population we are studying is homogeneous and some correlations with initial data might be interesting.

A start has been made, however, to attempt to follow the natural history of this difficult disease in a purposeful manner, and I hope to be able to produce some more useful results eventually.

I should like to take this opportunity to thank my co-workers in the Glaucoma Clinic at Moorfields, clerical as well as clinical, for their loyal and unstinting work in helping with this trial, and I should also like to thank the Medical Illustration Department at the Institute of Ophthalmology for their preparation of figures at short notice. I also much appreciate the help given to me in the Computer Department at the Institute. 